\title{
A Model of the Growth of Copper Selenide Thin Films Controlled by Diffusion and Chemical Reaction
}

\author{
Otávio Luiz Bottecchia \\ Departamento de Química, Universidade Federal de Uberlândia, Av. João Naves \\ D’Ávila 2160,38400-089 Uberlândia-MG,Brazil; email:otavio@ufu.br
}

Received: January 22, 1998

\begin{abstract}
Propõe-se um modelo de crescimento de filmes finos de seleneto de cobre. É apresentada uma equação matemática que descreve a cinética de crescimento do filme. São apresentados resultados simulados bem como discussão sobre os resultados do modelo. Fez-se um procedimento de ajuste dos dados derivados do modelo com resultados experimentais. Foi estimado o coeficiente de difusão dos íons $\mathrm{Cu}(\mathrm{I})$ em seleneto de cobre.

A model of the growth of thin films of copper selenides is proposed. A mathematical equation that describes the kinetics of the growth is derived. Simulated results and a discussion on the results of the model are presented. A fitting procedure of literature data with the derived equation is carried out. The diffusion coefficient of copper(I) ions in copper selenide is roughly estimated.
\end{abstract}

Keywords: copper selenide, growth mechanism, diffusion, thin films

\section{Introduction}

This paper deals with a theoretical description of the growth of thin films of copper selenide on copper substrate. Thin films of semiconductor materials like $\mathrm{Cu}_{2} \mathrm{Se}, \mathrm{ZnS}$, $\mathrm{GaAs}, \mathrm{CdS}, \mathrm{Cu}_{2} \mathrm{~S}, \mathrm{CuInSe}$, amongst others, are potentially alternative materials for substituting bulk silicon in electronic devices and particularly in photovoltaic systems. The drawback of silicon is its high production cost with the necessary purity. Use of thin films (1-10 $\mu \mathrm{m}$ thick) represents considerable cost saving because of reduced material use (ca. $20 \mathrm{~g} / \mathrm{m}^{2}$ ).

These films can be prepared in several ways. Low pressure vapour deposition is probably the technique which yields the best results, but requires sophisticated equipment. Electrochemical methods are supposed to be cheaper and they can be more easily adapted from laboratory to industrial scale. A very simple method is the chemical bath deposition. It is based on dipping a solid substrate in a conveniently formulated solution. More than one mechanism is possible in this case. The semiconductor can be formed at the solid/solution interface and then deposited onto the substrate. Cadmium sulphide was prepared by dipping a glass sheet in a solution containing $\mathrm{Cd}\left(\mathrm{NH}_{3}\right)_{4}{ }^{2+}$ and thiou- rea ${ }^{1}$. The latter slowly decomposes and generates sulphide ions while the former acts as a source of $\mathrm{Cd}(\mathrm{II})$. Both ions combine and generate $\mathrm{CdS}$, which deposits on the glass. $\mathrm{ZnS}$ was prepared similarly ${ }^{2}$.

Another mechanism operates when the substrate itself acts as source of metal ions of the semiconductor to be prepared. In this case, once the first monolayer is formed, it is necessary that metallic ions move through the film, since movement of selenium ions in copper selenides practically does not occur. Electrons also have to move towards the external interface and combine with some oxidizing agent in the neighbourhood. Aluminium, zirconium, copper and nickel oxides ${ }^{3}$ and copper selenide ${ }^{4}$ are formed in this way.

This work deals with a growth model of berzelianite, $\mathrm{Cu}_{2-\mathrm{x}} \mathrm{Se}$ (x representing a small deviation of the stoichiometry). $\mathrm{Cu}_{2-\mathrm{x}} \mathrm{Se}$ is a semiconductor with a band gap between 1.1 and $1.7 \mathrm{eV}$. The electronic transport properties are characterized by positive signs of the thermal emf and the Hall constant and by the negative temperature coefficient of electrical resistivity in certain temperature ranges. Apparently, the semiconductor type of properties results from the defect structure of $\mathrm{Cu}_{2-\mathrm{x}} \mathrm{Se}$ arising from the occurrence of vacancies in the $\mathrm{Cu}$ site, whose formation energy 
is characteristically low. The copper vacancies supposedly create low-lying acceptor levels in the bandgap that are occupied at ordinary temperatures, and the resultant holes in the valence band account for the hole conduction ${ }^{5}$.

Thin films of $\mathrm{Cu}_{2-x} \mathrm{Se}$ compound can be prepared by dipping copper metal in a sodium selenosulfate solution ${ }^{4}$.

$$
(2-\mathrm{x}) \mathrm{Cu}(\text { solid })+\mathrm{SeSO}_{3}{ }^{2-} \text { (aq.) } \rightarrow \mathrm{Cu}_{2-\mathrm{x}} \mathrm{Se}(\text { solid })+
$$
$\mathrm{SO}_{3}^{2-}$ (aq.)

The growth rate depends on the mobility of the metallic ion through the solid film. The less the diffusion coefficient in the solid, the lower the growth rate. As far as we know, the diffusion coefficient of $\mathrm{Cu}(\mathrm{I})$ in copper selenide has not yet been determined. The electrical conductivity is also important, for the electrons also have to move in order to maintain the electrical neutrality. However, this parameter is more important in a galvanostatic process (like the anodic formation of $\mathrm{Cu}_{2} \mathrm{~S}^{6}$ and $\mathrm{CdS}^{7}$ ) than in chemical bath deposition.

Control of the growth kinetics of semiconductor is prerequisite to the preparation of thin films with technological applications. With regard to $\mathrm{Cu}_{2-x} \mathrm{Se}$, the film grows according to the parabolic law ${ }^{4}, \delta=\mathrm{At}^{1 / 2}$, where $\delta$ is the film thickness, $\mathrm{t}$ is the immersion time of the substrate in the solution and $\mathrm{A}$ is a constant. Wagner ${ }^{8,9}$ deduced this law, assuming the existence of concentration differences in each phase.

For the growth of copper selenide in aqueous selenosulfate, the constant $\mathrm{A}$ is a function of the selenosulfate concentration ${ }^{4}$. This dependence is not predicted by the mathematical expression that defines this parameter. In order to explain the dependence, a model refinement is necessary. The basis for this can be the fact that traces of crutaite, $\mathrm{CuSe}_{2}$, were found in the film together with $\mathrm{Cu}_{2-\mathrm{x}} \mathrm{Se}$, depending on the experimental conditions ${ }^{4}$. This result led to the hypothesis that a sublayer of $\mathrm{CuSe}_{2}$ is formed before the formation of $\mathrm{Cu}_{2-x} \mathrm{Se}$. The gradient of chemical potential of $\mathrm{Cu}(\mathrm{I})$ at the $\mathrm{CuSe}_{2} /$ solution and the $\mathrm{Cu} / \mathrm{Cu}_{2-\mathrm{x}} \mathrm{Se}$ interfaces would be the driving force leading the reaction. Description of this process as well as its formulation established a new model for copper selenide growth. The aim of this paper is to present such a model. The parabolic law will still be considered valid, but the kinetics of the selenosulfate reduction and the formation of the sublayer will be included.

\section{The Model}

Figure 1 represents the steps supposed to occur during the growth of $\mathrm{Cu}_{2-\mathrm{x}} \mathrm{Se}$. First, before any reaction occurs, the substrate (copper metal) is put in contact with aqueous selenosulfate. As the substrate is homogeneous, the $\mathrm{Cu}(\mathrm{I})$ chemical potential profile is constant at some value at the metal and zero at the solution if it does not contain any copper ion.
Then, a first layer of $\mathrm{Cu}_{2-\mathrm{x}} \mathrm{Se}$ is formed by the attack of selenosulfate:

$$
(2-\mathrm{x}) \mathrm{Cu}+\mathrm{SeSO}_{3}{ }^{2-} \rightarrow \mathrm{Cu}_{2-\mathrm{x}} \mathrm{Se}+\mathrm{SO}_{3}{ }^{2-}
$$

The solubility product of copper selenide is quite low $\left(10^{-60.8} \mathrm{~mol}^{3} / \mathrm{L}^{3}\right.$, according to Ref. 10) and facilitates the occurrence of this reaction. The action of selenosulfate goes on and makes the surface richer in selenium. This leads to the formation of $\mathrm{CuSe}_{2}$. The formation of poliselenides is known ${ }^{11}$. The chemical potential of $\mathrm{Cu}(\mathrm{I})$ decreases in these two phases in relation to the one at the metal. Figure 1 represents the decrease as linear in the $\mathrm{CuSe}_{2}$ because this layer is always very thin, while the $\mathrm{Cu}_{2-\mathrm{x}} \mathrm{Se}$ layer grows. This hypothesis is reasonable because just traces of $\mathrm{CuSe}_{2}$ are found experimentally and no $\mathrm{CuSe}_{2}$ could be detected if the experiment is carried out faster ${ }^{4}$. The gradient of chemical potential leads to the diffusion of $\mathrm{Cu}(\mathrm{I})$ through both phases. When $\mathrm{Cu}(\mathrm{I})$ goes through the sublayer, the $\mathrm{CuSe}_{2}$ is converted into $\mathrm{Cu}_{2-\mathrm{x}} \mathrm{Se}$ :

$$
(3-2 x) \mathrm{Cu}^{+}+\mathrm{CuSe}_{2}+(3-2 \mathrm{x}) \mathrm{e} \rightarrow 2 \mathrm{Cu}_{2-\mathrm{x}} \mathrm{Se}
$$

$\mathrm{CuSe}_{2}$ is richer in selenium than $\mathrm{Cu}_{2-\mathrm{x}} \mathrm{Se}$ and accordingly $\mathrm{CuSe}_{2}$ is formed near the film/solution interface. The selenosulfate uptakes the electron generated by the $\mathrm{Cu}(\mathrm{I})$ formation. Then, it is assumed that these processes repeat $\mathrm{n}$ times.

\section{Mathematical Description}

The time for forming $\mathrm{CuSe}_{2}$ in each cycle is always the same. On the other hand, the diffusion time of $\mathrm{Cu}(\mathrm{I})$ through the layer and sublayer increases in each cycle, since their thicknesses increase gradually.

It is assumed that the rate of the chemical reaction is proportional to the sodium selenosulfate concentration, $\mathrm{C}$. The time required by the chemical reaction is given by:

$$
\mathrm{t}_{1}^{\prime}=\frac{\delta_{1}^{\prime}}{\mathrm{kC}}
$$

where $\delta_{1}$ 'is the thickness of the sublayer, $\mathrm{k}$ is the kinetic constant and the subscript indicates the number of the cycle.

The time required by $\mathrm{Cu}(\mathrm{I})$ to diffuse, $\mathrm{t}$ ", may be expected to obey the parabolic law. Thus t" is given by $\mathrm{t}^{\prime \prime}=(\delta / \mathrm{A})^{2}$, where $\delta$ is the thickness of the film to be crossed. So, after formation of the first $\mathrm{Cu}_{2-x} \mathrm{Se}$ layer, with thickness $\delta_{1}$, one has:

$$
t_{1}^{\prime \prime}=\frac{\left(\delta_{1}+\delta_{1}^{\prime}\right)^{2}}{A^{2}}
$$

Each cycle consists of these two steps. The time of each step in each cycle is named $\mathrm{t}_{2}{ }^{6}, \mathrm{t}_{2}{ }^{\prime}, \mathrm{t}_{3}{ }^{6}, \mathrm{t}_{3}{ }^{\prime},, \mathrm{t}_{\mathrm{n}}{ }^{6}, \mathrm{t}_{\mathrm{n}}{ }^{\prime}$, so that: 

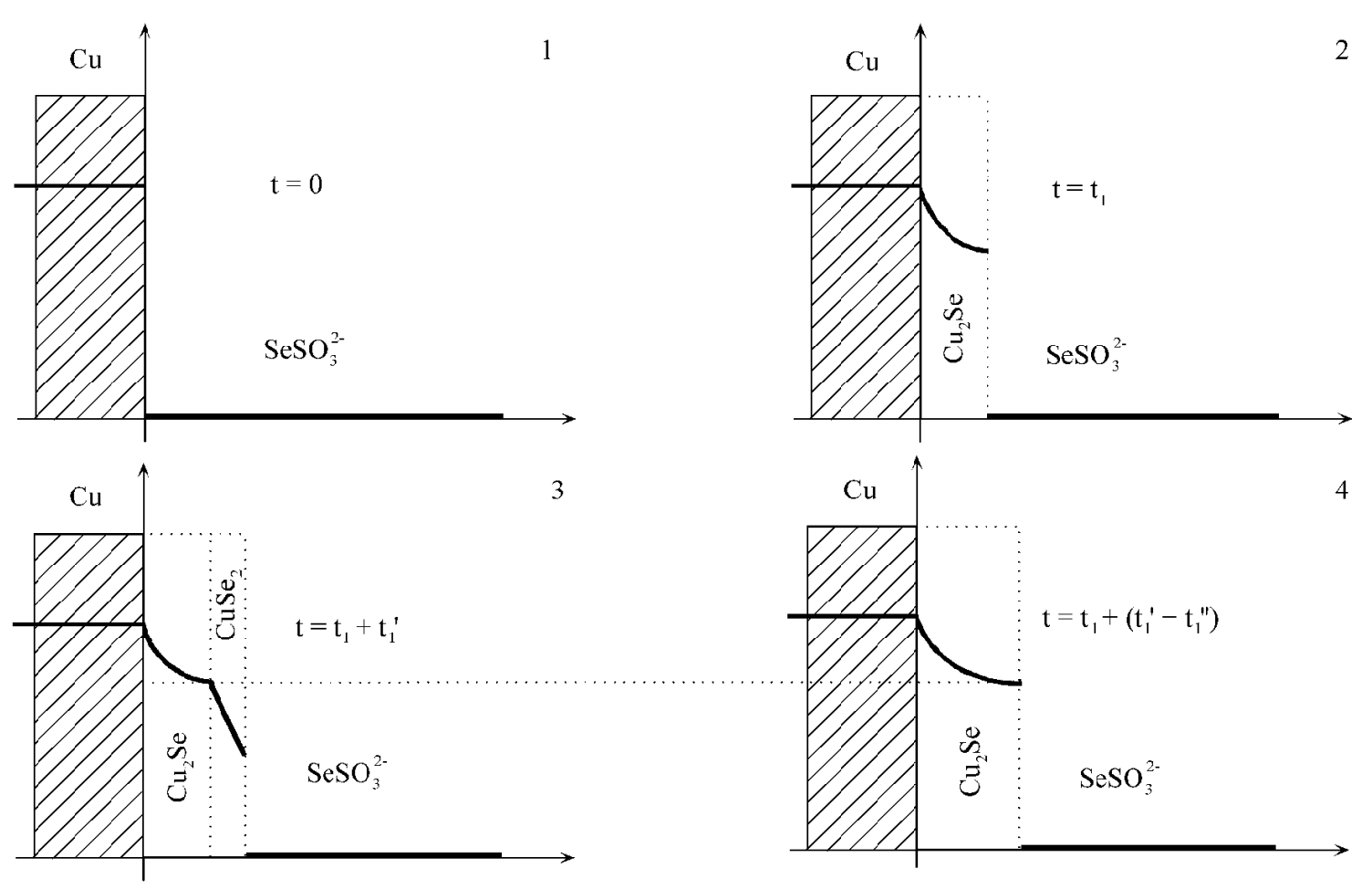

3
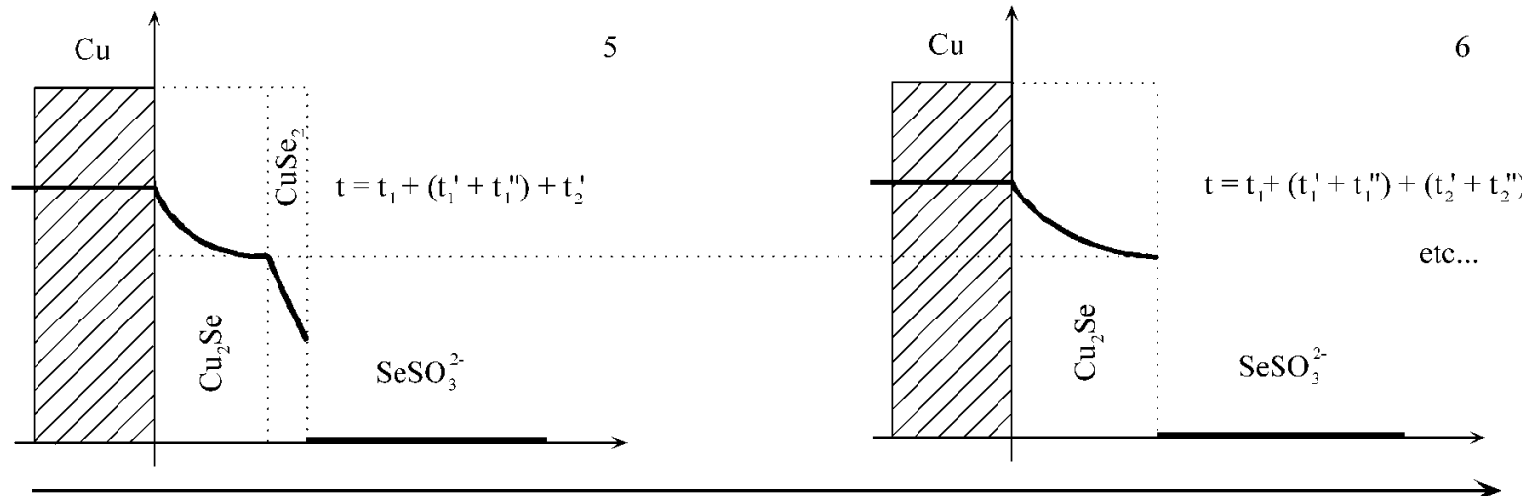

distance from the substrate

Figure 1. Proposed model of formation of $\mathrm{Cu}_{2-\mathrm{x}} \mathrm{Se}$ film on copper from aqueous sodium selenosulfate. Once a first monolayer of $\mathrm{Cu}_{2-\mathrm{x}} \mathrm{Se}$ is formed, it is attacked by selenosulfate ions, yielding a sublayer of $\mathrm{CuSe}_{2}$. Ions $\mathrm{Cu}(\mathrm{I})$ diffuse from the substrate towards the interface film/solution and convert $\mathrm{CuSe}_{2}$ to $\mathrm{Cu}_{2-\mathrm{x}} \mathrm{Se}$, increasing the thickness of the film. The process repeats $\mathrm{n}$ times.

$$
\begin{aligned}
& \mathrm{t}_{2}^{\prime}=\frac{\delta_{1}^{\prime}}{\mathrm{kC}}, \ldots, \mathrm{t}_{\mathrm{n}}^{\prime}=\frac{\delta_{\mathrm{i}}}{\mathrm{kC}} \\
& \mathrm{t}_{2}^{\prime \prime}=\frac{\left(\delta_{1}+2 \delta_{1}^{\prime}\right)^{2}}{\mathrm{~A}^{2}} \ldots \mathrm{t}_{\mathrm{n}=}^{\prime \prime} \frac{\left(\delta_{1}+\mathrm{n} \delta_{1}^{\prime}\right)^{2}}{\mathrm{~A}^{2}}= \\
&=\frac{\delta_{1}^{2}+2 n \delta_{1}^{\prime}+\mathrm{n}^{2}\left(\delta_{1}^{\prime}\right)^{2}}{\mathrm{~A}^{2}}
\end{aligned}
$$

$\delta=n \delta_{1}^{\prime}$

The time required for forming the film is the sum of the required time in each of the $n$ steps:

$\mathrm{t}=\left(\mathrm{t}_{1}^{\prime}+\mathrm{t}_{1}^{\prime \prime}\right)+\left(\mathrm{t}_{2}^{\prime}+\mathrm{t}_{2}^{\prime \prime}\right)+\left(\mathrm{t}_{3}^{\prime}+\mathrm{t}_{3}^{\prime \prime}\right)+\ldots+\left(\mathrm{t}_{\mathrm{n}}^{\prime}+\mathrm{t}_{\mathrm{n}}^{\prime \prime}\right)($

Substituting the terms t' and t" yields:

$$
\begin{aligned}
& \mathrm{t}=\sum_{\mathrm{i}=1}^{\mathrm{n}} \frac{\delta_{1}^{\prime}}{\mathrm{kC}}+\frac{1}{\mathrm{~A}^{2}} \sum_{\mathrm{i}=1}^{\mathrm{n}}\left(\delta_{1}^{2}+2 \mathrm{i} \delta_{1} \delta_{1}^{\prime}+\mathrm{i}^{2}\left(\delta_{1}^{\prime}\right)^{2}\right) \\
& \mathrm{t}=\frac{\mathrm{n} \delta_{1}^{\prime}}{\mathrm{kC}}+\frac{1}{\mathrm{~A}^{2}} \mathrm{n} \delta_{1}^{2}+\frac{1}{\mathrm{~A}^{2}} \sum_{\mathrm{i}=1}^{\mathrm{n}}\left(2 \mathrm{i} \delta_{1} \delta_{1}^{\prime}+\mathrm{i}^{2}\left(\delta_{1}^{\prime}\right)^{2}\right)
\end{aligned}
$$

$$
\delta=\sum_{\mathrm{i}=1}^{\mathrm{n}} \delta_{\mathrm{i}}^{\prime}
$$


Using the identities ${ }^{12}$

$$
\sum_{i=1}^{n} i=\frac{n(n+1)}{2}, \sum_{i=1}^{n} 1^{2}=\frac{n(n+1)(2 n+1)}{6},
$$

the following equation can be obtained:

$$
\begin{array}{r}
\mathrm{t}=\left(\frac{\delta_{1}^{\prime}}{\mathrm{kC}}+\frac{\delta_{1}^{2}}{\mathrm{~A}^{2}}+\frac{\delta_{1} \delta_{1}^{\prime}}{\mathrm{A}^{2}}+\frac{\left(\delta_{1}^{\prime}\right)^{2}}{6 \mathrm{~A}^{2}}\right) \mathrm{n}+\left(\frac{\delta_{1} \delta_{1}^{\prime}}{\mathrm{A}^{2}}+\frac{\left(\delta_{1}^{\prime}\right)^{2}}{2 \mathrm{~A}^{2}}\right) \mathrm{n}^{2}+ \\
+\left(\frac{\left(\delta_{1}^{\prime}\right)^{2}}{3 \mathrm{~A}^{2}}\right) \mathrm{n}^{3}
\end{array}
$$

Substitution of (1) in (2) results:

$$
\begin{array}{r}
\mathrm{t}=\left(\frac{1}{\mathrm{kC}}+\frac{\delta_{1}^{2}}{\delta_{1}^{\prime} \mathrm{A}^{2}}+\frac{\delta \mathrm{l}}{\mathrm{A}^{2}}+\frac{\delta_{1}^{\prime}}{6 \mathrm{~A}^{2}}\right) \delta+\left(\frac{\delta \mathrm{l}}{\delta_{1}^{\prime} \mathrm{A}^{2}}+\frac{1}{2 \mathrm{~A}^{2}}\right) \delta^{2}+ \\
+\left(\frac{1}{3 \delta_{\mathrm{i}}^{\prime} \mathrm{A}^{2}}\right) \delta^{3}(15)
\end{array}
$$

\section{Results and Discussion}

The growth of copper selenides was simulated assig-

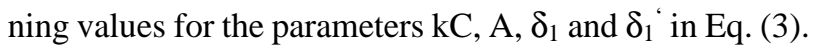
Figure 2 shows some curves generated in this way. The value used both for $\delta_{1}$ and for $\delta_{1}$ ' was $6 \times 10^{-8} \mathrm{~cm}$, which corresponds approximately to the dimension of a monolayer of copper selenide. The size of a unit cell in the crystal lattice of copper selenide is ${ }^{13} \mathrm{ca} .5 .8 \times 10^{-8} \mathrm{~cm}$. Values of $\mathrm{A}^{2}$ and of the product $\mathrm{kC}$ have dimensions of $\mathrm{cm}^{2} / \mathrm{s}$ and $\mathrm{cm} / \mathrm{s}$, respectively. These parameters varied from $10^{-8}$ to $10^{-10} \mathrm{~cm}^{2} / \mathrm{s}$ and from infinity $(1 / \mathrm{kC}=0)$ to $10^{-8} \mathrm{~cm} / \mathrm{s}$.

The growth curve increases monotonically, is concave downwards and has no asymptote. The concavity is a consequence of the terms $\delta^{2}$ and $\delta^{3}$ in Eq. (3) and of the fact that their coefficients are always positive. There is a linear region, whose extension depends on $\mathrm{kC}$ and $\mathrm{t}$. If $\mathrm{kC}$ is small compared to $\delta_{1}{ }^{~} \mathrm{~A}^{2} / \delta_{1}{ }^{2}, \mathrm{~A}^{2} / \delta_{1}$ and $\mathrm{A}^{2} / \delta_{1}$, the first term of the second member in Eq. (3) predominates over the other terms. The Eq. (3) simplifies and becomes linear. This linear region means that the chemical reaction is the rate determining step of the growth. The film growth is also linear at the initial stages of formation, i.e., if t tends to zero. In this case, the film is so thin, that the transport of $\mathrm{Cu}(\mathrm{I})$ occurs easily and does not constitute hindrance to the growth. Obviously, the smaller is $\mathrm{kC}$, the smaller is the linear interval.

If Eq. (3) cannot be simplified, then diffusion of $\mathrm{Cu}(\mathrm{I})$ is the rate determining step. Thus, kinetic information is predominantly contained at the initial part of the growth curve, while information about ion transport is contained at the non linear region.

Equation (3) was fitted to the experimental result of Ref. 4, varying the parameters $\mathrm{A}^{2}$ and $\mathrm{kC}$. Initially both parameters were fixed at low values, and $\mathrm{A}^{2}$ was increased.

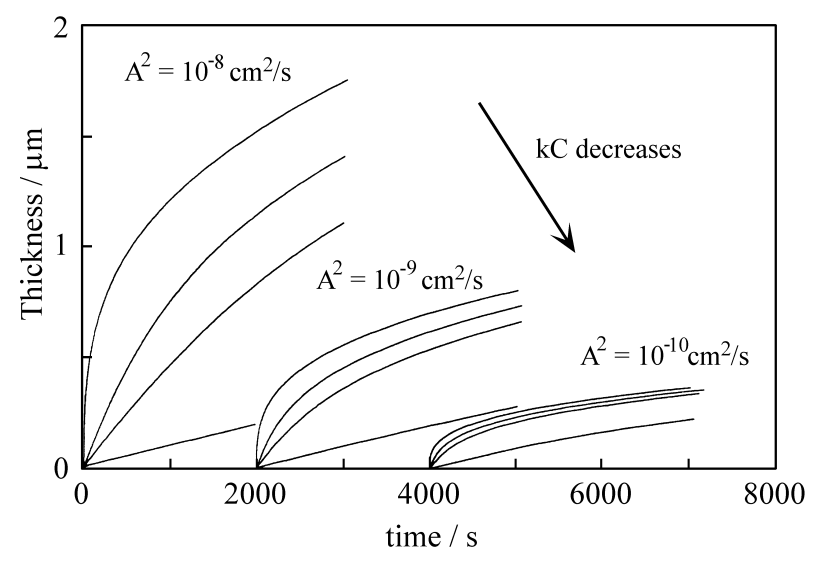

Figure 2. Hypotethical growth curves of copper selenide film according to the proposed model. Used parameters: $\delta_{1}=\delta_{1}{ }^{\prime}=6 \times 10^{-8} \mathrm{~cm}$. For clarity, the curves were separated in three series, shifted $2000 \mathrm{~s}$ from each other: (1) $\mathrm{A}^{2}=10^{-10} \mathrm{~cm}^{2} / \mathrm{s}$; (2) $\mathrm{A}^{2}=10^{-9} \mathrm{~cm}^{2} / \mathrm{s}$ and (3) $\mathrm{A}^{2}=$ $10^{-8} \mathrm{~cm}^{2} / \mathrm{s}$. In each group the parameters $\mathrm{kC}$ were: $\diamond$ (i.e., $1 / \mathrm{kC}=0$ ),

The low values of $\mathrm{kC}$ yield linear plots. Then the concavity was corrected by increasing kC. Deviations caused by this last increase were compensated by varying $A^{2}$. Figure 3 shows the results obtained with $\mathrm{A}^{2}=10^{-8} \mathrm{~cm}^{2} / \mathrm{s}$ and $\mathrm{k}=7.9$ $x 10^{-6} \mathrm{~cm} \mathrm{~s}^{-1} \mathrm{~L} \mathrm{~mol}^{-1}$.

The agreement between calculations and experimental data by itself does not validate the model but permits estimation of physico chemical parameters. The diffusion coefficient of $\mathrm{Cu}(\mathrm{I})$ in $\mathrm{Cu}_{2-\mathrm{x}} \mathrm{Se}$ can be calculated from $\mathrm{A}^{2}$ if the difference of $\mathrm{Cu}(\mathrm{I})$ concentration in copper selenide and in copper metal is known. (see appendix):

$$
\mathrm{A}=\frac{\mathrm{M}_{\mathrm{Cu}_{2} \mathrm{Se}}}{\rho_{\mathrm{Cu}_{2} \mathrm{Se}}} \Delta \mathrm{C}_{\mathrm{Cu}(\mathrm{I})} \mathrm{D}_{\mathrm{Cu}(\mathrm{I})}
$$

This concentration is related to the number of defects per unit volume of the crystal. The reader is referred to

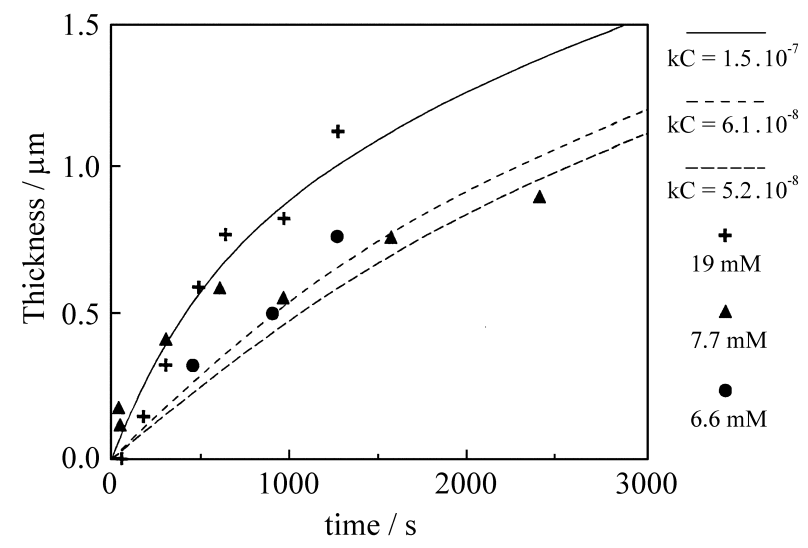

Figure 3. Comparison of experimental and theoretical curves. Parameters used in Eq. (3): $\mathrm{A}^{2}=10^{-8} \mathrm{~cm} / \mathrm{s} ; \delta_{1}=\delta_{1}{ }^{\prime}=6 \times 10^{-8} \mathrm{~cm}$; the parameters $\mathrm{kC}$ at the figure correspond to the same value of $\mathrm{k}=7.9 \times 10^{-6}$ $\mathrm{cm} \mathrm{s}^{-1} \mathrm{M}^{-1}$, $\mathrm{C}$ being the given sodium selenosulfate concentration. 
Morrison ${ }^{14}$ for more details. Typically, the number of defects may be of the order $10^{16} \mathrm{~cm}^{-3}$, according to Bamford and Tipper ${ }^{15}$. Assuming the number of defects in copper metal to be much lower than the one in copper selenide, $\Delta \mathrm{C}_{\mathrm{Cu}(\mathrm{I})}$ can be assumed to be $10^{16} \mathrm{~cm}^{-3}=1.66 \times 10^{-8} \mathrm{~mol}$ $\mathrm{cm}^{-3}$. By using this value with the value of A obtained experimentally and the density and molar mass of the $\mathrm{Cu}_{2} \mathrm{Se}$ equal to $6.749 \mathrm{~g} / \mathrm{cm}^{3}$ and $206.0 \mathrm{~g} / \mathrm{mol}$, respectively, one obtains $2 \times 10^{-10} \mathrm{~cm}^{2} \mathrm{~s}^{-1}$ as an estimate for the coefficient of diffusion of copper. This value can be compared with the diffusion coefficient of $\mathrm{Cu}(\mathrm{I})$ in a similar compound, copper sulphide. According to Etienne ${ }^{16}$, the diffusion coefficient of $\mathrm{Cu}(\mathrm{I})$ in chalcocite is $\mathrm{D}_{\mathrm{Cu}(\mathrm{I})}=8.1 \times 10^{-3} \mathrm{e}^{(-5870 / \mathrm{T})}$, and in digetite is $\mathrm{D}_{\mathrm{Cu}(\mathrm{I})}=3.6 \times 10^{-2} \mathrm{e}^{(-6100 / \mathrm{T})}$, where $\mathrm{T}$ is the thermodynamic temperature. At room temperature $(300 \mathrm{~K})$ the values are respectively $2.6 \times 10^{-11}$ and $5.3 \times 10^{-11} \mathrm{~cm}^{2} / \mathrm{s}$. On the basis of these calculations, $\mathrm{Cu}(\mathrm{I})$ may have a mobility four to eight times greater in copper selenide than in copper sulphide.

Since there is in other models no other equivalent parameter to $\mathrm{k}$, it is difficult to compare its value. The ratio $\mathrm{A}^{2} / \mathrm{k}$ has dimensions length times molarity (of sodium $\langle \%-2\rangle$ selenosulfate). Its experimental value, $1.26 \times 10^{-3} \mathrm{~cm} \mathrm{~mol} \mathrm{~L}^{-1}$ reveals that the diffusion limits the growth much more than the rate of sublayer formation.

Finally, a remark about the magnitude of $\delta_{1}$ and $\delta_{1}$ 'must be made. As mentioned, the value $6 \times 10^{-8} \mathrm{~cm}$ used for these parameters is approximately the thickness of a copper selenide monolayer. The appropriate $\delta_{1}$ and $\delta_{1}$ 'values might be expected to be greater if selenium could diffuse into the film towards the metal concomitantly with $\mathrm{Cu}(\mathrm{I})$ movement. Then the film would grow at the film/solution interface as well as at the film/substrate interface. However this seems to be improbable, because selenium has practically no mobility in copper selenide ${ }^{13}$.

\section{Conclusion}

A model for the growth of copper selenide on copper from selenosulfate solution was presented. The model assumes that the enrichment with selenium of the layer adjacent to solution leads to formation of a sublayer of $\mathrm{CuSe}_{2}$. Diffusion of $\mathrm{Cu}(\mathrm{I})$ from the substrate leads to film growth. The time necessary for the growth varies according to a polynomial function of third degree of the thickness. The terms of superior degree are a consequence of the diffusion hindrance. The principal parameters that determine the properties of the growth curve are diffusion coefficient, rate constant, thickness of the sublayer and activity of $\mathrm{Cu}(\mathrm{I})$ in the film. By comparing experimental and simulated growth curves, the diffusion coefficient of $\mathrm{Cu}(\mathrm{I})$ in copper selenide was estimated as $2 \times 10^{-10} \mathrm{~cm}^{2} \mathrm{~s}^{-1}$. The precision of this value depends on knowledge of the chemical potential of $\mathrm{Cu}(\mathrm{I})$ in copper selenide relative to the one in metallic copper.

\section{Appendix}

This appendix shows that the diffusion of $\mathrm{Cu}(\mathrm{I})$ (without considering the formation of a sublayer) leads to the parabolic law. The deduction, based on Booth ${ }^{17}$, will be adapted to the growth of copper selenide.

Let $\mathrm{V}$ be the volume of $\mathrm{Cu}_{2} \mathrm{Se}$ (density $\rho$ ) formed on a constant surface area A with thickness $\delta$ at the instant t, growing unidimensionally along the $\mathrm{x}$-coordinate, from $\mathrm{x}=0$. The mass of $\mathrm{Cu}_{2} \mathrm{Se}$ is related with these parameters according to:

$$
\mathrm{V}=\mathrm{Ax}=\left(\frac{\mathrm{m}}{\rho}\right)_{\mathrm{Cu}_{2} \mathrm{Se}}
$$

Inserting the molar mass $\mathrm{M}$ of copper selenide and deriving with relation to $t$, one has:

$$
\mathrm{A} \frac{\mathrm{dx}}{\mathrm{dt}}=\left(\frac{\mathrm{M}}{\rho}\right)_{\mathrm{Cu}_{2} \mathrm{Se}} \frac{\mathrm{dnCu}_{2} \mathrm{Se}}{\mathrm{dt}}
$$

Stoichiometry requires that $\mathrm{dn}_{\mathrm{Cu} 2 \mathrm{Se}}=1 / 2 \mathrm{dn}_{\mathrm{Cu}(\mathrm{I})}$. In absence of an external electric field, the consumption of ions $\mathrm{Cu}(\mathrm{I})$ is related to the gradient of concentration, according to first Fick's law ${ }^{18}$ :

$$
\frac{\mathrm{dn}_{\mathrm{Cu}(\mathrm{I})}}{\mathrm{dt}}=\mathrm{D}_{\mathrm{Cu}(\mathrm{I})}\left(\frac{\partial \mathrm{C}_{\mathrm{Cu}(\mathrm{I})}}{\partial \mathrm{x}}\right) \mathrm{x}=\delta
$$

So, for an area of $1 \mathrm{~cm}^{2}$ :

$$
\frac{\mathrm{dx}}{\mathrm{dt}}=\frac{1}{2}\left(\frac{\mathrm{M}}{\rho}\right)_{\mathrm{Cu}_{2} \mathrm{Se}} \mathrm{D}_{\mathrm{Cu}(\mathrm{I})}\left(\frac{\partial \mathrm{C}_{\mathrm{Cu}(\mathrm{I})}}{\partial \mathrm{x}}\right)_{\mathrm{x}}=\delta
$$

Supposing that the concentration gradient is uniform, then it can be written that:

$$
\begin{aligned}
& \frac{\mathrm{dx}}{\mathrm{dt}}=\frac{1}{2}\left(\frac{\mathrm{M}}{\rho}\right)_{\mathrm{Cu}_{2} \mathrm{Se}} \mathrm{D}_{\mathrm{Cu}(\mathrm{I})} \frac{\Delta \mathrm{C}_{\mathrm{Cu}(\mathrm{I})}}{\mathrm{x}}, \\
& \int_{0}^{\delta} \mathrm{x} \mathrm{dx}=\frac{1}{2}\left(\frac{\mathrm{M}}{\rho}\right)_{\mathrm{Cu}_{2} \mathrm{Se}} \mathrm{D}_{\mathrm{Cu}(\mathrm{I})} \Delta \mathrm{C}_{\mathrm{Cu}(\mathrm{I})} \int_{0}^{\mathrm{t}} \mathrm{dt} \\
& \mathrm{d}=\mathrm{At} 1 / 2
\end{aligned}
$$

with $\mathrm{A}=\left(\left(\frac{\mathrm{M}}{\rho}\right)_{\mathrm{Cu}_{2} \mathrm{Se}} \Delta \mathrm{C}_{\mathrm{Cu}(\mathrm{I})} \mathrm{D}_{\mathrm{Cu}(\mathrm{I})}\right)^{1 / 2}$, which is the desired demonstration.

\section{Acknowledgement}

Stimulating discussions, led by Dr. H. Wendt in his work group at the Technische Hochschule Darmstadt, Germany, directed me to the ideas presented in this work. I thank him for the opportunity of participating in those discussions. 


\section{References}

1. Doña, J.M.; Herrero, J. J. Electrochem. Soc. 1992, $139,2810$.

2. Doña, J.M.; Herrero, J. J. Electrochem. Soc. 1994, 141, 205.

3. Moore, J. J. Chem. Phys. 1950, 18, 231.

4. Wendt, H.; Schimmel, M.I.; Bottecchia, O.L. J. Appl. Electrochem. 1998, 28(3), 299-304.

5. Chakrabarti, D.J.; Laughlin, D.E. Bull. of Alloy Phase Diagrams 1981, 2(3), 305-315.

6. Wendt, H.; Schimmel, M.I.; Bottecchia, O.L. In: Annals of the Fourth European Symposium on Electrochemical Engineering, 1996, Prague, Czech Republic, p. 73.

7. Peter, L.M. Electrochim. Acta 1978, 23, 1073.

8. Wagner, C. Z. Physik. Chem. 1933, B21, 25.

9. Wagner, C. Z. Physik. Chem. 1936, B32, 447.
10. Smith, R.M.; Martell, A.E. In Critical Stability Constants, Plenum Press, NY, 1976, vol. 4.

11. Lingane, J.J.; Niedrach, L.W. J. Am. Chem. Soc. 1949 , $71,196$.

12. Tsypkin, A.G.; Tsypkin, G.G. Fórmulas Matemáticas, Ed. Mir, Moscow, 1990, chap. 4.

13. Gmelins Handbuch der anorganischen Chemie, 1936, 8. Auflage, System nummer 60, p. 603.

14. Morrison, S.R. In Electrochemistry at Semiconductor and Oxidised Metal Electrodes, Plenum Press, NY, 1980, chap. 1.

15. Bamford, C.H.; Tipper, C.F.H. In The Theory of Kinetics, Elsevier Scientific Publishing Co., 1969, vol. 2, p. 421.

16. Etienne, A. J. Electrochem. Soc. 1970, 117, 870.

17. Booth, F. Trans. Faraday Soc. 1948, 44, 796.

18. Crank, J. Mathematics of Diffusion, Claredon Press, Oxford, 1956, chap. 1. 